Original Research Paper

\title{
Evaluation of Keratinolytic Activity Succeeds by Keratinophilic Fungi in Jaipur, India
}

\author{
${ }^{1}$ Vishnu Sharma, ${ }^{2}$ Anima Sharma and ${ }^{1}$ Ruchi Seth \\ ${ }^{1}$ Department of Biotechnology, JECRC University, Jaipur, India \\ ${ }^{2}$ Department of Animal Genetics and Breeding, \\ ICAR-Central Sheep and Wool Research Institute, Arid-Region Campus, Bikaner, India
}

Article history

Received: 20-09-2016

Revised: $18-10-2016$

Accepted: 17-10-2016

Corresponding Author: Anima Sharma

Department of Animal Genetics \& Breeding, ICAR-

Central Sheep and Wool

Research Institute, Arid-

Region Campus, Bikaner, India

Email: sharmaanima6@gmail.com

\begin{abstract}
Earth has innate background for fungi that cover individual kingdom since evolution. The keratinophilic fungi are allied moulds that produce the keratinase enzyme to degrade the keratinous materials in or on the soil. Keratinous materials are insoluble and resistant to degradation by common proteinase enzymes. It is important to study the microorganism producers of such enzymes for use in the biotechnology industry. In order to present study, two isolates of fungi were evaluated to determine if they had the ability to degrade keratin as nutrient substrate. They were grown in an inundated culture medium containing poultry feathers. Among species, best keratin substrate degradation activity as well as keratinase enzyme activity was recorded in Arthoderma multifidium (KU578107) followed by Chrysosporium tropicum (KU578108) gradually leading manner day by days.
\end{abstract}

Keywords: Arthoderma multifidium, Chrysosporium tropicum, Enzyme, Filamentous Fungi, Keratin

\section{Introduction}

In poultry processing industry with market demand of contemptible meat, the feathers wastes are gradually increasing day by day. Especially in India, around 350 million tons per year poultry waste is produced from processing industries that are discarded or used for land filling and burned or buried (Agrahari and Wadhwa, 2010; Agrawal and Dalal, 2015; Kumawat et al., 2016). The feather constitutes by $\beta$ keratin, a fibrous protein that highly cross-linked with disulfide bonds and appeared initial in 3-dimensional folds (Brandelli et al., 2010; Sharma et al., 2015a). These keratin wastes can be proficiently degraded by precise proteases such as keratinase. Keratinase is proteases which able to degrade the scleroprotein keratin that is produced by a domain of saprophytic and dermatophytes fungi, actinomycetes and other microbial species (Selvam and Vishnupriya, 2012; Sharma et al., 2015b). These groups contain a complex group of hydrolytic enzymes that disgrace to proteins into small amino acids. These hydrolytic enzymes attack on the carbonyl carbon of the scissile bond where the peptide bonds are cleaved by catalysis in addition of water (Bhat, 2000; Kumawat et al., 2013). Therefore, this present study was aimed to evaluate the degradation of keratin from feather degradation medium and to estimate a potential use of keratinase from keratinocytes fungi origin for the industrial treatment of keratin containing materials.

\section{Materials and Methods}

\section{Soil Collection}

The collection of soil samples was based on higher contamination of keratin at Jaipur. Soil samples were collected from the open roadside, public park, poultry farm house, slaughter house and barbershop dump area. The soil samples were taken by sterile spatula from the surface part and the depth was not exceeding $4-5 \mathrm{~cm}$.

\section{Isolation of Keratinophilic Fungi}

The baiting technique of Vanbreuseghem was employed to isolate keratinophilic fungi from soil samples (Vanbreuseghem, 1952; Kumar et al., 2013). Sixty grams of soil samples were transferred into 90 $\mathrm{mm}$ sterile petri dishes and then the small piece of keratinous substances were aseptically spread on top of the soil sample. After that, the sterile distilled water (15-18 mL) was poured on the keratinous substrate baited plates. The baited plates were incubated at $27+2{ }^{\circ} \mathrm{C}$ under low light for $21-25$ days. The fungal $/$ mold growths were appeared on the all keratinous substrates baited plates after 21-25 days. After that, the 
fungal growths were culture and transferred on the slants of potato dextrose agar (Hi-Media) for pure culture isolation, identification and future analysis.

\section{Identification of Isolated Fungi}

After the preliminary examination, fungal growth was identified on the basis of macroscopic, microscopic and $18 \mathrm{~S}$ rRNA sequencing. The Sequence was then submitted to NCBI Genbank.

(http://www.ncbi.nlm.nih.gov/Genbank/index.html).

\section{Screen out the Keratinolytic Potential of Identified Keratinophilic Fungi}

Fungi produce proteases a group of proteinases and peptidases with varying itself nature basis on species (Chaturvedi et al., 2013; Anand et al., 1990). In the present study, the keratin degradation by keratinophilic fungal species (Chrysosporium tropicum and Arthoderma multifidium) was evaluated using modified feather degradation medium $\left(\mathrm{K}_{2} \mathrm{HPO}_{4}-1.25 \mathrm{~g} ; \mathrm{MgSO}_{4} .7 \mathrm{H}_{2} \mathrm{O}-0.025\right.$ g; $\mathrm{CaCL}_{2}-0.02 \mathrm{~g} ; \mathrm{FeSO}_{4} .7 \mathrm{H}_{2} \mathrm{O}-0.015 \mathrm{~g} ; \mathrm{ZnSO}_{4} .7 \mathrm{H}_{2} \mathrm{O}-0.005$ $\mathrm{g}$; $\mathrm{pH} 7.0 \pm 0.2$ ) for estimation of keratinolytic potential. In the process, the spore suspensions of 15 days old culture of each fungal species were inoculated in sterilized flask containing $100 \mathrm{~mL}$ of the $\mathrm{FDM}$ and $250 \mathrm{mg}$ of keratin substrate and incubated at $27 \pm 2^{\circ} \mathrm{C}$ on the orbital incubating shaker at $70 \mathrm{rpm}$ for 15 days.

\section{Keratinase Enzyme Activity of Keratinophilic Fungi}

The specific classes of proteolytics also contain keratinase that catalyze the hydrolysis of keratin substrates (Awasthi and Kushwaha, 2011). After 3-4 days, with the growth of fungal mycelium, there was started the consumption of keratin substrate and release an extracellular enzyme known as keratinase. In the mid of inoculation, on 4, 8, 12 and 16 day, After respective day's incubation, mycelium was removed by filtration and the filtrated was centrifuged at $10000 \mathrm{rpm}$ using cooling centrifuged for $10 \mathrm{~min}$ and the supernatant was used as a crude enzyme (Riffel et al., 2003; Kim, 2003). Keratinase activity was evaluated by the modified method of $\mathrm{Yu}$ et al. (1968). In the method, 20 mg of chicken feathers powder was suspended in 3.8 $\mathrm{mL}$ of $100 \mathrm{~nm}$ Tris-HCL buffer with $\mathrm{pH}$ 7.8. About 200 $\mu \mathrm{L}$ of the centrifuged enzyme filtrate was added. The mixture was incubated to process keratinolytic reaction at $37^{\circ} \mathrm{C}$ for $1 \mathrm{~h}$. Then the mixture was dipped into ice cold water for $10 \mathrm{~min}$ for shutting down the keratinolytic reaction. Finally, the mixture was filtered to remove a residue of remain feathers. Then the clear mixture was measured at $280 \mathrm{~nm}$ for absorbance by GE Healthcare Ultrospec ${ }^{\mathrm{TM}} 8000$ Dual-beam UV-Visible Spectrophotometer. The keratinase activity was measured and expressed as one unit of the enzyme corresponding to an increase absorbance value 0.1 (1 $\mathrm{KU}=0.100$ corrected absorbance), $\mathrm{KU}=$ keratinase unit (Jaroslava et al., 2014).

\section{Results}

\section{Isolation and Identification}

Soil samples from Jaipur were enriched in featherdegrading microorganisms. On the basis of initial baiting keratinolytic screening, isolates were selected for further identification. As per the cultural, microscopic and molecular identification, these fungal species were identified as Arthoderma multifidium (KU578107) and Chrysosporium tropicum (KU578108).

\section{Keratinolytic Potential of Identified Fungi}

After keratin degradation feather degrading media, the residual feathers were harvested from the fermentation media by filtering it through Whatman filter paper.

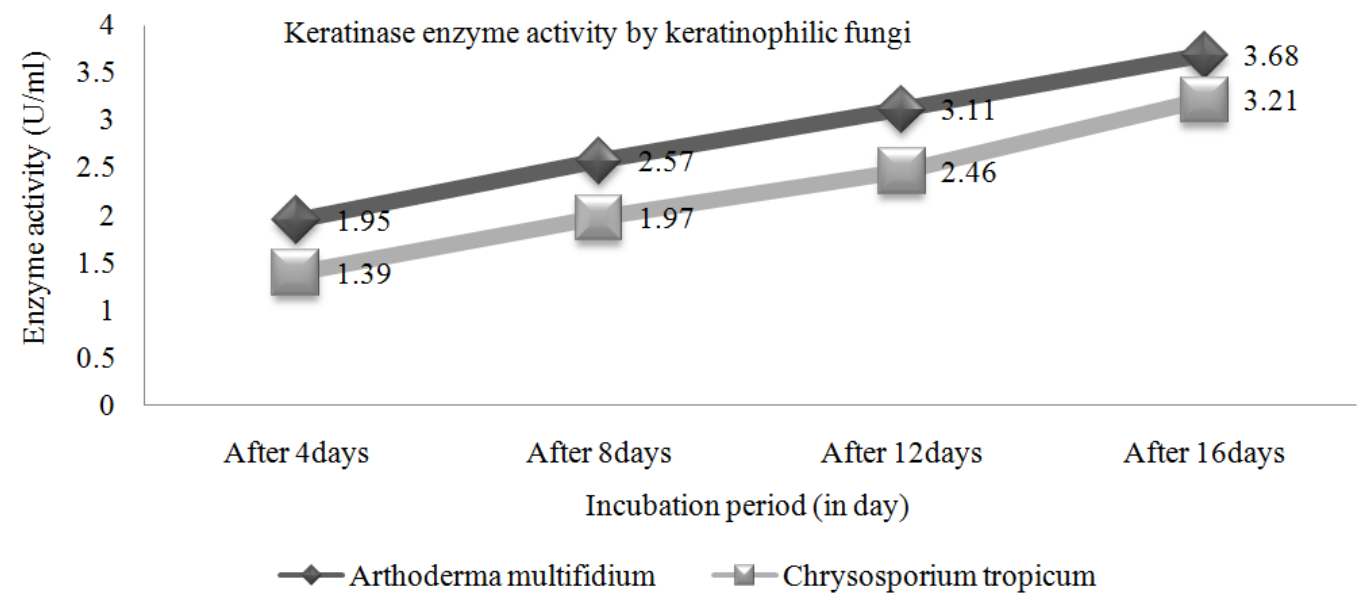

Fig. 1. Graphical representation of keratinase enzyme activity 
Table 1. Final $\mathrm{pH}$ and the keratin degradation potential for each sample

\begin{tabular}{lll}
\hline Sample name & & \multicolumn{2}{c}{ Keratin degradation } \\
Arthoderma multifidum & Final pH of medium & 7.42 \\
Chrysosporium tropicum & 7.39 & ++ \\
\hline
\end{tabular}

- No inhibition; + Fair inhibition; ++ Excellent inhibition

A final $\mathrm{pH}$ of the culture filtrates was determined by calibrated $\mathrm{pH}$ meter. The presence of keratinous feather degradation was calculated in the positive or negative mode to verify the keratinolytic nature of selected species indicating with + for positive and - for negative (Table 1). Among the keratinophilic fungal species, best keratin substrate degradation activity was recorded in Arthoderma multifidium followed by Chrysosporium tropicum. The alkalinity of the medium was changed possibly due to the production of cysteine, keratinase and proteins. Observation was also showed that the fungi, although deamination and alkalization of the medium due to excretion of excess nitrogen via deamination and ammonium excretion, surely engage in the activity of keratinolysis (Fig. 1). Possibly in degradation, the disulphide linkage involves rupturing between the peptide chains of keratin molecules by some extra and intra cellular enzymes collectively called keratinizing activity (Buxman, 1981). In keratinase enzyme activity, both species were found positive for protease activity.

Subsequently in evaluation of keratinase enzyme activity by dermatophytic fungi, the keratinase enzyme activity was started in an increasing pattern during incubation period. In the present study, the best activity was recorded on 16 days of incubation in a gradually rising manner from 4th day of incubation. Among the same, the highest keratinolytic activity was recorded in Arthoderma multifidium (3.68 $\mathrm{U} \mathrm{mL}^{-1}$ ) with followed by Chrysosporium tropicum $\left(3.21 \mathrm{U} \mathrm{mL}^{-1}\right)$. These extracellular enzymes secreted by these fungi are responsible for the degradation of keratin in nature.

\section{Discussion}

Enzymes are the catalytic keystone of metabolic actions of living organisms. Enzymes play a role as proteins with possessing its properties as particular towards the reactions that they catalyze and also as substrates on which they function upon (Bhat, 2000). The Fungal extracellular enzymes help to break keratin's macromolecules into micro molecules which they can absorb. For it, they require carbon substance as a source of energy and nitrogen substance to build protein and another essential compound. Further, a group of enzymes can be secreted simultaneously to target multiple nutrients (Chaturvedi et al., 2013; Anand et al., 1990). Keratinase is produced by various bacteria, actinomycetes and fungi in an optimum range of physical parameters (Farag and Hassan, 2004; Thys et al., 2004;
Anbu et al., 2005). In the presented study, our study reports similar to Sousa et al. (2015; Jaroslava et al., (2014). In subsequence, Kushwaha and Agarwal (1976) isolated the same species from the Sagar, Madhya Pradesh, India. In Jaipur, a study was reported on the presence of Chrysosporium tropicum from soil samples of public park by Sharma and Sharma (2009). At Andhra Pradesh, India, Ramakrishnaiah et al. (2013) isolated five types of indigenous fungi from the decaying poultry feather samples and their enzymatic activity. In this study, feather degradation was determined visually. According to the graph, it is confirmed that Arthoderma multifidum and Chrysosporium tropicum fungi are also possessed a protease proficient of reducing disulfide bonds of keratin. Further optimization of the process needs to be done to make it suitable for commercial use. This includes optimization of feather concentration with the fungi directly as well as the isolated enzyme.

\section{Conclusion}

In Environment, the keratinase enzymes from keratinolytic organisms have used in animal feed processing, sewage treatment and even environmental bioremediation. In this study, both species (Arthoderma multifidum and Chrysosporium tropicum are a potential keratinolytic fungi which are suitable for the degradation of natural keratin wastes. There is a need to carry out further studies on these isolates to facilitate commercialization uses as catalysts in biotechnological applications involving bioremediation and hydrolytic reactions with an established degradation of the chicken feathers and other keratin containing wastes in environment.

\section{Acknowledgement}

The authors are indebted to Head, Department of Biotechnology, JECRC University, Jaipur. A grateful acknowledgment is to NCCPF, PGIMER, Chandigarh for support in the molecular analysis of isolated fungal cultures.

\section{Author's Contributions}

All authors equally contributed in this work.

\section{Ethics}

This article is original and contains unpublished material. The corresponding author confirms that all of 
the other authors have read and approved the manuscript and no ethical issues involved.

\section{References}

Agrahari, S. and N. Wadhwa, 2010. Degradation of chicken feather a poultry waste product by keratinolytic bacteria isolated from dumping site at Ghazipur poultry processing plant. Int. J. Poult. Sci., 9: 482-489. DOI: 10.3923/ijps.2010.482.489

Agrawal, B. and M. Dalal, 2015. Screening and characterization of keratinase enzyme obtained from keratin degrading microorganism isolated from Sanjan poultry waste dumping soil. Eur. Acad. Res., 2: 13986-19994.

Anand, L., S. Krishnamurthy and P.J. Vithayanthil, 1990. Purification and properties of xylanase from the thermophilic fungus, Humicola lanuginosa (Griffon and Maublanc) Bunce. Arch. Biochem. Biophys., 276: 546-553. PMID: 2306111

Anbu, P., S.C.B. Gopinath, A. Hilda, P.T. Lakshmi and G. Annadurai, 2005. Purification of keratinase from poultry farm isolate-Scopulariopsis brevicaulis and statistical optimization of enzyme activity. Enzyme Microb. Technol., 36: 639-647. DOI: 10.1016/j.enzmictec.2004.07.019

Awasthi, P. and R.K.S. Kushwaha, 2011. Keratinase activity of some hyphomycetes fungi from dropped off chicken feathers. Int. J. Pharm. Biol. Sci. Arch., 2: 1745-1750.

Bhat, M.K., 2000. Cellulases and related enzymes in biotechnology. Biotechnol. Adv., 18: 355-383. DOI: 10.1016/S0734-9750(00)00041-0

Brandelli, A., D.J. Daroit and A. Riffel, 2010. Biochemical features of microbial keratinases and their production and applications. Applied Microbiol. Biotechnol., 85: 1735-1750. DOI: 10.1007/s00253-009-2398-5

Buxman, M.M., 1981. Enzyme of keratinization. Int. J. Dermatol., 20: 95-98.

Chaturvedi, S., S. Pathak, R. Upadhyay and S. Dubey, 2013. Comparative study of dermatophytic fungi for extra cellular proteases efficacy. Res. Rev.: J. Microbiol. Biotechnol., 2: 66-77.

Farag, A.M. and M.A. Hassan, 2004. Purification, characterization and immobilization of a keratinase from Aspergillus oryzae. Enzyme Microb. Technol., 34: 85-93. DOI: 10.1016/j.enzmictec.2003.09.002

Jaroslava, K., D. Tancinova and J. Medo, 2014. Production of extracellular keratinase by Chrysosporium tropicum and Trichophyton ajelloi. J. Microbiol. Biotech. Food Sci., 3: 103-106.

Kim, J.D., 2003. Keratinolytic activity of five Aspergillus species isolated from poultry farming soil in Korea. Mycobiology, 31: 157-161.

DOI: $10.4489 / \mathrm{MYCO} .2003 .31 .3 .157$
Kumar, R., R. Mishra, S. Maurya and H.B. Sahu, 2013. Isolation and identification of keratinophilic fungi from garbage waste soils of Jharkhand region of India. Eur. J. Exp. Biol., 3: 600-604.

Kumawat, T.K., A. Sharma and S. Bhadauria, 2016. Biodegradation of keratinous waste substrates by arthroderma multifidum. Asian J. Applied Sci., 9: 106-112.

Kumawat, T.K., V. Sharma, R. Seth and A. Sharma, 2013. Diversity of keratin degrading fungal flora in industrial area of Jaipur and keratinolytic potential of Trichophyton mentagrophytes and Microsporum canis. IJBBR, 4: 359-364.

Kushwaha, R.K.S. and S.C. Agarwal, 1976. Some keratinophilic fungi and related dermatophytes from soil. Proc. Ind. Natn. Sci. Acad., 42: 102-110.

Ramakrishnaiah, G., S.M. Mustafa and G. Srihari, 2013. Studies on keratinase producing fungi isolated from poultry waste and their enzymatic activity. J. Microbiol. Res., 3: 148-151.

DOI: $10.5923 /$ j.microbiology.20130304.04

Riffel, A., S. Ortolan and A. Brandelli, 2003. De-hairing activity of extracellular proteases produced by keratinolytic bacteria. J. Chem. Technol. Biotechnol., 78: 855-859. DOI: 10.1002/jctb.828

Selvam, K. and B. Vishnupriya, 2012. Biochemical and molecular characterization of microbial keratinase and its remarkable applications. Int. J. Pharm. Biol. Sci. Arch., 3: 267-275.

Sharma, M. and M. Sharma, 2009. Influence of environmental factors on the growth and Sporulation of Geophilic Keratinophiles from soil samples of Public Park. Asian J. Exp. Sci., 23: 307-312.

Sharma, V., T.K. Kumawat, A. Sharma, R. Seth and S. Chandra, 2015a. Distribution and prevalence of dermatophytes in semi-arid region of India. Adv. Microbiol., 5: 93-106. DOI: 10.1002/jctb.828

Sharma, V., T.K. Kumawat, R. Seth and A. Sharma, 2015b. Dermatophytes: Diagnosis of dermatophytosis and its treatment. Afri. J. Micro. Res., 9: 1286-1293.

Sousa, A.M., A.L. Politani, G.Z.S. Junior, R.M.C. Rodrigues and R.M.P. Alvarenga, 2015. Acute transverse myelitis and dengue: A systematic review. Trop. Med. Surg., 3: 178-178.

Thys, R.C.S., F.S. Lucas, A. Riffel, P. Heeb and A. Brandelli, 2004. Characterization of a protease of a feather-degrading microbacterium species. Lett. Applied Microbiol., 39: 181-186.

DOI: $10.1111 /$ j.1472-765X.2004.01558.x

Vanbreuseghem, R., 1952. Technique biologique pour L'isolement des dermatophytes du sol. Ann. Soc. Belg. Trop., 32: 173-178.

$\mathrm{Yu}$, R.J., S.R. Harmon and F. Blank, 1968. Isolation and purification of an extracellular keratinase of Trichophyton mentagrophytes. J. Bacteriol., 96: 1435-1436. 